\title{
MENINGKATKAN HASIL BELAJAR SISWA PADA MATA PELAJARAN \\ PKN MENGGUNAKAN METODE PEMBELAJARAN TIPE JIGSAW KELAS V SD NEGERI 164518 KOTA TEBING TINGGI
}

\section{Dameria Ompusunggu}

Surel: Ibudameria173@gmail.com

\begin{abstract}
ABSTRAK
Penelitian ini bertujuan untuk meningkatkan hasil belajar siswa mata pelajaran PKn melalui metode pembelajaran Jigsaw. Metode penelitian ini adalah penelitian tindakan kelas (PTK). Subjek penelitian ini adalah siswa kelas V SD Negeri 164518 kota Tebing Tinggi. Penelitian ini menggunakan teknik analisis dekriptif kualitatif. Pembelajaran dengan metode Jigsaw pada materi pelajaran PKn di kelas V SD Negeri 164518 Kota Tebing Tinggi memiliki dampak positif dalam meningkatkan hasil belajar siswa yang ditandai dengan peningkatan ketuntasan belajar siswa dalam setiap siklus, yaitu prasiklus $(55,26 \%)$ siklus I $(68,42 \%)$, siklus II $(86,68 \%)$ dinyatakan berhasil.
\end{abstract}

Kata Kunci : Hasil Belajar, Model Jigsaw, PKN

\section{PENDAHULUAN}

Belajar tidak selamanya memiliki serta arti sebagai sesuatu yang semata-mata bersifat intelektualitas saja, tetapi menyangkut juga segi-segi lain, seperti misalnya pengamatan untuk memperoleh gambaran yang pengertiannya agak jelas. Dalam kehidupan sehari-hari, baik dalam bidang kemasyarakatan dan lebih dalam bidang pendidikan masalah belajar merupakan masalah yang cukup menarik untuk dibicarakan. Oleh sebab itu, tidak heran bila banyak cendikiawan yang mencoba untuk menerangkan atau membuat rumusan tentang belajar.

Pengembangan dan mendidik anak didik untuk terus mampu berpikir harus dijadikan landasan pelaksanaan pengajaran dan pendidikan, termasuk pada pengajaran PKn. Jika guru benarbenar aktif dan kreatif tidak akan kehabisan bahan untuk mengembangkan pikiran anak didik dan terus belajar untuk menjadikan anak didik prioritas sehingga mencari apa dan bagaimana membuat anak didik lebih cepat dan mampu memahami dan menerima pelajaran yang diberikan guru.

Penguraian latar belakang masalah di atas maka peneliti dalam melakukan penelitian ini memberi judul: Meningkatkan Hasil Belajar Siswa Mata Pelajaran PKN Menggunakan Metode Pembelajaran Tipe Jigsaw Kelas V SD Negeri 164518 Kota Tebing Tinggi Tahun Pelajaran 2014/2015.

Identifikasi masalah dalam penelitian ini adalah:

a. Menyajikan materi pembelajaran guru masih menggunakan metode 
monoton sehingga siswa merasa bosan.

b. Hasil belajar siswa masih rendah karena tidak dapat menerima dan memahami pelajaran yang disampaikan guru dengan baik.

Sesuai dengan judul di atas peneliti mengadakan penelitian yang menitikberatkan pada masalah. Apakah metode pembelajaran Jigsaw mampu membantu meningkatkan hasil belajar siswa kelas V pada mata pelajaran PKn di SD Negeri 164518 Kota Tebing Tinggi tahun pelajaran 2014/2015?

Tujuan penelitian tindakan kelas (PTK) pada kelas V SD Negeri 164518 mata pelajaran PKN melalui metode pembelajaran tipe Jigsaw adalah sebagai berikut:

1. Mengetahui bagaimana metode tipe jigsaw dapat meningkatkan pemahaman siswa kelas $\mathrm{V}$ SD Negeri 164518 Tebing Tinggi.

2. Mengetahui hasil belajar siswa menggunakan pembelajaran tipe jigsaw siswa kelas V SD Negeri 164518 Tebing Tinggi.

Adapun manfaat dari penelitian ini adalah:

Manfaat bagi Siswa

a) Diharapkan dapat mengubah pola pikir siswa bahwa pelajaran PKN sangat penting dipelajarin.

b) Diharapkan mampu menerapkan prinsip-prinsip kerjasama dalam kelompoknya.

c) Menghilangkan kebosanan siswa ketika proses belajar mengajar berlangsung.
Manfaat bagi Guru

a) Meningkatkan profesionalisme guru dalam interaksi belajar mengajar.

b) Guru mengenal karakter dan kemampuan siswa sehingga akan mempermudah dalam proses mengajar.

c) Memperbaiki proses belajar mengajar.

Manfaat bagi Sekolah

a) Mengukur mutu hasil pendidikan.

b) Dengan meningkatnya hasil belajar siswa dapat menjadi dewan bagi sekolah dalam menentukan arah kebijakan obyek dalam penelitian tindakan kelas dan akan memperoleh hasil pengembangan ilmu.

\section{METODE PENELITIAN}

Penelitian dilaksanakan di SD Negeri 164518 Jalan Pulau Samosir Kota Tebing Tinggi, Kel. Rantau Laban, Kec. Padang Hulu, Tahun Pelajaran 2014/2015.

Subjek penelitian adalah siswa kelas V SD Negeri 164518 Kota Tebing Tinggi Tahun Pelajaran 2014/2015 dengan jumlah siswa sebanyak 38 siswa 19 laki-laki dan 19 perempuan.

Waktu Penelitian Tindakan Kelas yaitu tepat pada bulan September-November 2014. Adapun rencana tindakan penelitian ini adalah siklus I pada tanggal 20 September 2014 dan siklus II pada tanggal 08 Oktober 2014. 
Prosedur atau langkahlangkah yang akan dilakukan dalam penelitian ini dilaksanakan dalam kegiatan dengan model Kemmis dan Taggart (dalam Sugiarti, 1997:6), seperti bagan berikut:

\section{Model Penelitian Tindakan Kelas}

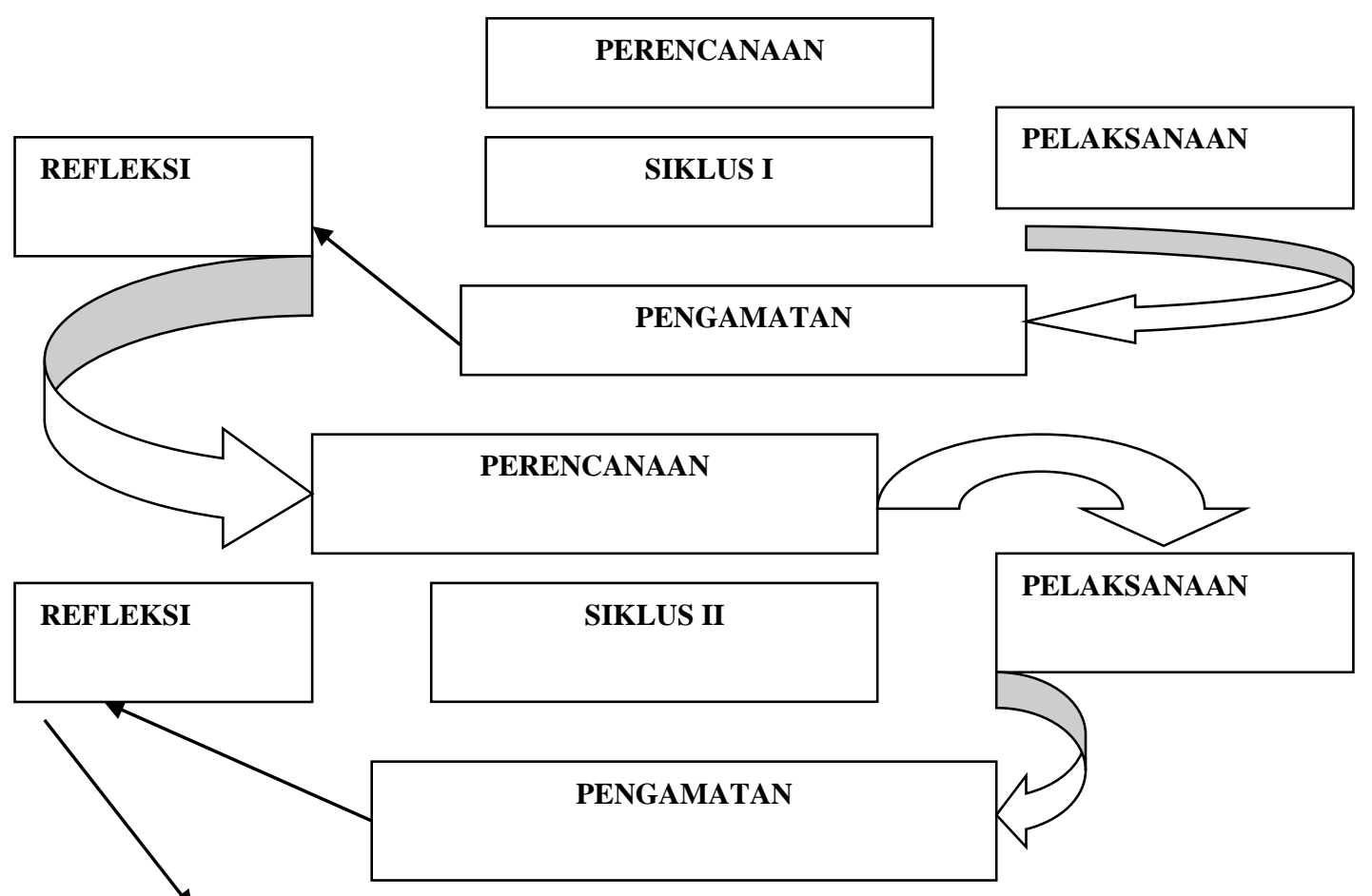

Siklus 1

Siklus pertama dalam PTK ini terdiri dari perencanaan, pelaksanaan, pengamatan dan refleksi sebagai berikut:

Perencanaan (planning)

a. Peneliti melakukan analisis kurikulum untuk mengetahui kompetensi dasar yang akan disampaikan kepada siswa dengan menggunakan pembelajaran tipe Jigsaw.

b. Membuat rencana pelaksanaan pembelajaran tipe Jigsaw

Pelaksanaan (acting)

1. Membagi siswa dalam kelompok
2. Memberikan penjelasan tentang kompetensi yang ingin dicapai

3. Memberikan penjelasan skenario Jigsaw

4. Salah satu dari kelompok mendemonstrasikan skenario Jigsaw

5. Penguatan dan kesimpulan bersama-sama

6. Guru memberikan kuis/ pertanyaan

7. Siswa diberikan kesempatan untuk memberikan tanggapan

8. Melakukan pengamatan/ observasi

Pengamatan (observation)

a. Situasi kegiatan belajar mengajar 
b. Minat dan ketertarikan siswa

c. Kemampuan siswa dalam Jigsaw

Refleksi (Reflecting)

Penelitian tindakan kelas ini berhasil apabila:

a. Sebagian besar $<75 \%$ dari siswa mampu menjawab pertanyaan dari guru

b. Lebih dari $80 \%$ siswa berminat dalam proses belajar

c. Penyelesaian tugas kelompok sesuai dengan waktu yang ditentukan

\section{Siklus 2}

Seperti halnya siklus pertama, siklus kedua pun terdiri dari perencanaan, pelaksanaan, pengamatan dan refleksi.

Perencanaan (Planning)
Peneliti membuat rencana
pembelajaran berdasarkan hasil
refleksi pada siklus pertama.

\section{Pelaksanaan (Acting)}

Guru melaksanakan pembelajaran kooperatif dengan tipe Jigsaw berdasarkan rencana pembelajaran hasil refleksi pada siklus pertama.

\section{Pengamatan (Observation)}

Peneliti (guru dan kolaborator) melakukan pengamatan terhadap minat belajar siswa dalam pembelajaran tipe Jigsaw.

\section{Refleksi (Reflecting)}

Peneliti melakukan refleksi terhadap pelaksanaan siklus ke dua dan menganalisis serta membuat kesimpulan atas pelaksanaan pembelajaran tipe Jigsaw dalam meningkatkan hasil belajar siswa dalam pembelajaran PKn di kelas V SD Negeri 164518.

\section{Teknik Pengumpulan Data}

Pengumpulan data dalam penelitian ini menggunakan metode observasi dan dokumentasi dengan tujuan untuk mengamati dan mengetahui kegiatan belajar mengajar di kelas, praktikum, satuan pelajaran dan lembar kegiatan siswa yang digunakan sekolah.

\section{Teknik Analisa Data}

Penelitian ini termasuk dalam kategori Penelitian Tindakan (Action Research). Penelitian ini juga termasuk penelitian deskriptif, sebab menggambarkan bagaimana suatu teknik pembelajaran diterapkan dan bagaimana hasil yang diinginkan dapat dicapai. Tujuan utama dari penelitian tindakan ini adalah meningkatkan hasil pembelajaran di kelas dimana guru secara penuh terlibat dalam penelitian mulai dari perencanaan, tindakan, pengamatan dan refleksi.

Secara jelas siklus yang terdiri dari empat tahap dapat diuraikan sebagai berikut:

Perencanaan (Planning)

Kegiatan yang dilakukan pada tahap perencanaan sebagai berikut:

a. Menetukan hipotesis tindakan yaitu: "Hasil belajar siswa dalam pembelajaran materi dengan 
menggunakan metode pembelajaran jigsaw".

b. Menganalisis kelayakan hipotesis setelah alternatif tindakan penulis ditentukan, kemudian penulis kaji lagi kelayakannya dikaitkan dengan kemungkinan pelaksanaannya. Hal ini terkait dengan hal-hal berikut:

1) Kemampuan dan komitmen guru

2) Kemampuan siswa

3) Ketersediaan fasilitas

c. Menyusun RPP

Dalam menyusun RPP dicantumkan:

Skenario pembelajaran:

- Kegiatan Awal

- Kegiatan Inti

- Kegiatan Akhir

- Evaluasi

2) Menyiapkan sarana pembelajaran, media pembelajaran, buku penunjang, dan sumber bahan ajar lainnya.

Pelaksanaan

Pelaksanaan dilakukan di dalam ketika proses belajar mengajar sedang berlangsung dengan siswa dibagi perkelompok, kemudian setiap kelompok memilih ketua kelompok agar dapat memimpin kelompoknya masing-masing dalam belajar menggunakan model jigsaw.

Pengamatan

Pengamatan dilaksanakan bersama-sama dengan pelaksanaan. Dalam kegiatan pengamatan menggunakan lembar pengamatan kerja guru. Lembar pengamatan unjuk kerja guru dilakukan oleh teman sejawat. Selain mengamati kinerja guru dalam kegiatan belajar mengajar, teman sejawat juga dimintai bantuan penulis untuk berdiskusi mencari penyebab masalah serta alternatif pemecahan masalah tersebut.

Penelitian ini adalah penelitian kualitatif sehingga untuk menganalisisnya menggunakan metode diskriptif analitik. Data yang diperoleh melalui observasi dan dokumentasi akan dikemukakan apa adanya sesuai dengan informasi yang telah diperoleh peneliti kemudian dianalisis sehingga dapat diketahui sejauh mana pendekatan keterampilan proses dilaksanakan.

Instrumen Penelitian

Untuk mendapatkan data penelitian digunakan instrumen sebagai berikut:

a. Lembar rencana pelaksanaan pembelajaran

b. Lembar observasi kelas yang digunakan untuk pengamat selama proses pembelajaran

c. Lembar hasil tes akhir untuk mengetahui hasil belajar siswa terhadap materi yang dipelajari

\section{HASIL DAN PEMBAHASAN Hasil penelitian Siklus 1}

Pelaksanaan penelitian ini berbentuk siklus yang terdiri dari 2 siklus yang masing-masing meliputi planning, acting, observing dan replecting. Masing-masing siklus terdiri dari 2 pertemuan. Tiap siklus 
dilaksanakan sesuai dengan tujuan yang ingin dicapai.

Permasalahan yang belum dapat dipecahkan dalam siklus pertama direfleksikan bersama tim peneliti dalam suatu pertemuan kolaborasi, untuk mencari penyebabnya, selanjutnya peneliti merencanakan berbagai langkah perbaikan untuk diterapkan pada siklus 2 .

Planning

a. Guru mempersiapkan instrumen penelitian, yaitu lembar observasi guru dan siswa dari catatan lapangan.

b. Guru mempersiapkan perangkat pembelajaran, yaitu satuan pelajaran, rencana pembelajaran dengan tipe belajar Jigsaw.

c. Guru memberikan penjelasan tentang apa yang ada di materi dengan memberikan contoh dengan yang sesuai materi yang ada.

Acting

a. Pilihlah materi pelajaran yang dapat dibagi menjadi beberapa segmen (bagian).

b. Bagilah siswa menjadi beberapa kelompok sesuai dengan jumlah segmen yang ada.

c. Setiap kelompok mendapat tugas membaca dan memahami materi yang berbeda-beda.

d. Setiap kelompok mengirimkan anggotanya ke kelompok lain untuk menyampaikan apa yang telah mereka pelajari di kelompok. e. Kembalikan suasana kelas seperti semula kemudian tanyakan sekiranya ada persoalan-persoalan yang tidak terpecahkan dalam kelompok.

f. Sampaikan beberapa pertanyaan kepada siswa untuk mengecek pemahaman mereka terhadap materi.

Observing

Tabel Hasil belajar Pkn siswa SD Negeri 164518 kelas $V$

\begin{tabular}{|c|c|c|c|c|}
\hline No & NIS & Nama Siswa & $\begin{array}{c}\text { Pra } \\
\text { Siklus }\end{array}$ & Siklus I \\
\hline 1. & 1737 & $\begin{array}{l}\text { ALYA } \\
\text { SUWITA }\end{array}$ & 70 & 72 \\
\hline 2. & 1738 & $\begin{array}{l}\text { ANGELICA } \\
\text { THANIA }\end{array}$ & 71 & 73 \\
\hline 3. & 1739 & $\begin{array}{l}\text { ANGGI } \\
\text { RAMADHANI }\end{array}$ & 65 & 70 \\
\hline 4. & 1740 & $\begin{array}{l}\text { ARIF FATU } \\
\text { LLAH }\end{array}$ & 63 & 67 \\
\hline 5. & 1741 & $\begin{array}{l}\text { DISTI } \\
\text { AMELIA } \\
\text { PUTRI } \\
\end{array}$ & 66 & 70 \\
\hline 6. & 1742 & $\begin{array}{l}\text { DIVA } \\
\text { HABIBAH Br. } \\
\text { SIMBOLON }\end{array}$ & 72 & 75 \\
\hline 7. & 1893 & $\begin{array}{l}\text { EKA } \\
\text { RAHMADANI }\end{array}$ & 68 & 68 \\
\hline 8. & 1743 & $\begin{array}{l}\text { ERZA } \\
\text { ADHITYA } \\
\text { MAULANA }\end{array}$ & 55 & 63 \\
\hline 9. & 1744 & $\begin{array}{l}\text { FARHAN } \\
\text { AZIZI }\end{array}$ & 72 & 75 \\
\hline 10. & 1745 & $\begin{array}{l}\text { FATHIR } \\
\text { SYAH AMIR } \\
\text { SITOMPUL }\end{array}$ & 64 & 68 \\
\hline 11. & 1746 & $\begin{array}{l}\text { HAFRIZA } \\
\text { HASANAH }\end{array}$ & 71 & 71 \\
\hline 12. & 1747 & $\begin{array}{l}\text { HALIZA } \\
\text { AZURA }\end{array}$ & 63 & 68 \\
\hline 13. & 1748 & $\begin{array}{l}\text { ICAH } \\
\text { ARDANI } \\
\text { PURBA }\end{array}$ & 65 & 67 \\
\hline 14. & 1750 & $\begin{array}{l}\text { IMAM } \\
\text { ADITYA }\end{array}$ & 80 & 81 \\
\hline 15. & 1751 & $\begin{array}{l}\text { JAKA BAGUS } \\
\text { PANGESTU }\end{array}$ & 75 & 77 \\
\hline 16. & 1752 & $\begin{array}{l}\text { JOYCE } \\
\text { FEBRYAN } \\
\text { BANGUN }\end{array}$ & 78 & 80 \\
\hline
\end{tabular}




\begin{tabular}{|c|c|c|c|c|}
\hline 17. & 1753 & $\begin{array}{l}\text { KEVIN } \\
\text { BACTIAR }\end{array}$ & 81 & 82 \\
\hline 18. & 1754 & $\begin{array}{l}\text { MEIKA } \\
\text { ANANDA } \\
\text { PRISKARINI }\end{array}$ & 77 & 80 \\
\hline 19. & 1755 & $\begin{array}{l}\text { MHD. ARIF } \\
\text { IRAWAN }\end{array}$ & 65 & 70 \\
\hline 20. & 1756 & $\begin{array}{l}\text { MHD. AZLI } \\
\text { PRADANA }\end{array}$ & 67 & 68 \\
\hline 21. & 1757 & $\begin{array}{l}\text { MHD. HALIM } \\
\text { NUROHO }\end{array}$ & 63 & 67 \\
\hline 22. & 1758 & $\begin{array}{l}\text { MHD. REZA } \\
\text { ALFIANDA }\end{array}$ & 80 & 80 \\
\hline 23. & 1759 & M. FAUZAN & 72 & 73 \\
\hline 24. & 1813 & $\begin{array}{l}\text { M. RAMZI } \\
\text { REKSADANA }\end{array}$ & 70 & 71 \\
\hline 25. & 1760 & $\begin{array}{l}\text { M. SYURAIH } \\
\text { AL HAQUE }\end{array}$ & 69 & 70 \\
\hline 26. & 1761 & $\begin{array}{l}\text { NABILA } \\
\text { KHAIRUNNIS } \\
\text { A }\end{array}$ & 63 & 67 \\
\hline 27. & 1762 & $\begin{array}{l}\text { NADILA } \\
\text { SIFHA }\end{array}$ & 58 & 62 \\
\hline 28. & 1763 & $\begin{array}{l}\text { NAJWA } \\
\text { AULIA } \\
\text { SARAGIH }\end{array}$ & 70 & 71 \\
\hline 29. & 1764 & $\begin{array}{l}\text { NAZWA } \\
\text { AZRININDIT } \\
\text { A }\end{array}$ & 70 & 71 \\
\hline 30. & 1769 & REISNA & 70 & 72 \\
\hline
\end{tabular}

\section{Siklus 1}

Refleksi

Hasil observasi, catatan lapangan peneliti dan kolaborator selama berlangsungnya pertemuan 1 dapat diuraikan sebagai berikut:

Faktor Guru

a. Semua tindakan yang direncanakan dapat dilakukan walaupun hasilnya belum optimal.

b. Guru dapat melakukan intropeksi atas kekurangan-kekurangan dan berinisiatif untuk memperbaikinya pada pertemuan berikutnya.

Adapun kendala yang dihadapi pada pertemuan I tersebut adalah:

\begin{tabular}{|l|l|l|l|l|}
\hline & & SYAFITRI & & \\
\hline 31. & 1767 & $\begin{array}{l}\text { RIDHO } \\
\text { ARYA }\end{array}$ & 75 & 75 \\
\hline 32. & 1768 & $\begin{array}{l}\text { RIZKI } \\
\text { RIANDA }\end{array}$ & 64 & 65 \\
\hline 33. & 1770 & $\begin{array}{l}\text { SAMUEL } \\
\text { RAPINDO } \\
\text { MANURUNG }\end{array}$ & 71 & 71 \\
\hline 34. & 1729 & $\begin{array}{l}\text { SISKA EFA } \\
\text { ANGGRAINI }\end{array}$ & 70 & 72 \\
\hline 35. & 1896 & $\begin{array}{l}\text { SIVANA } \\
\text { MAWADDAH }\end{array}$ & 66 & 67 \\
\hline 36. & 1771 & $\begin{array}{l}\text { SUCI } \\
\text { NURHIDAYA } \\
\text { H }\end{array}$ & 75 & 75 \\
\hline 37. & 1773 & $\begin{array}{l}\text { SYARIFUDDI } \\
\text { N }\end{array}$ & 65 & 70 \\
\hline 38. & 1775 & $\begin{array}{l}\text { ZAHWA } \\
\text { AULIA } \\
\text { SAFYAN }\end{array}$ & $\mathbf{7 3}$ & 75 \\
\hline Jumlah & & $\begin{array}{l}\mathbf{6 9 3 2} \\
\mathbf{6}\end{array}$ & $\mathbf{7 1 , 5 5}$ \\
\hline Rata-rata & $\begin{array}{l}\mathbf{5 5 , 2} \\
\mathbf{6 \%}\end{array}$ & $\begin{array}{l}\mathbf{6 8 , 4 2} \\
\mathbf{2 7 1 9}\end{array}$ \\
\hline Ketuntasan & & & \\
\hline
\end{tabular}

a. Guru merasa kaku dan canggung sehingga dalam memberikan instruksi kurang tegas, gerak kurang leluasa. Hal tersebut dikarenakan kehadiran kolaborator dan keterikatan pada tipe pembelajaran yang sedang dilaksanakan.

b. Kurangnya intermezo untuk memecahkan kekakuan siswa dan mengatasi situasi jam terakhir terutama menjelang berakhirnya jam pelajaran.

\section{Rencana Perbaikan}

Guru mencoba menerapkan kembali perencanaan pada pertemuan 1 dengan lebih baik karena dirasakan kinerja guru belum optimal dan 
rencana tindakan belum sepenuhnya dilaksanakan dengan baik.

\section{Siklus 2}

1) Planning

Rencana tindakan pada pertemuan ini sama dengan pertemuan sebelumnya.

2) Action

a. Pilihlah materi pelajaran yang dapat dibagi menjadi beberapa segmen (bagian).

b. Bagilah siswa menjadi beberapa kelompok sesuai dengan jumlah segmen yang ada.

c. Setiap kelompok mendapat tugas membaca dan memahami materi kuliah yang berbedabeda.

d. Setiap kelompok mengirimkan anggotanya ke kelompok lain untuk menyampaikan apa yang telah mereka pelajari di kelompok.

e. Kembalikan suasana kelas seperti semula kemudian tanyakan sekiranya ada persoalan-persoalan yang tidak terpecahkan dalam kelompok.

f. Sampaikan beberapa pertanyaan kepada siswa untuk mengecek pemahaman mereka terhadap materi.

\section{Observing}

\section{Tabel Hasil belajar Pkn siswa SD} Negeri 164518 kelas V

\begin{tabular}{|c|c|l|c|}
\hline No & NIS & \multicolumn{1}{|c|}{ Nama Siswa } & Siklus II \\
\hline 1. & 1737 & ALYA SUWITA & 75 \\
\hline 2. & 1738 & $\begin{array}{l}\text { ANGELICA } \\
\text { THANIA }\end{array}$ & 75 \\
\hline 3. & 1739 & $\begin{array}{l}\text { ANGGI } \\
\text { RAMADHANI }\end{array}$ & 75 \\
\hline
\end{tabular}

\begin{tabular}{|c|c|c|c|}
\hline 4. & 1740 & ARIF FATULLAH & 72 \\
\hline 5. & 1741 & $\begin{array}{l}\text { DISTI AMELIA } \\
\text { PUTRI }\end{array}$ & 70 \\
\hline 6. & 1742 & $\begin{array}{l}\text { DIVA HABIBAH } \\
\text { Br. SIMBOLON }\end{array}$ & 78 \\
\hline 7. & 1893 & $\begin{array}{l}\text { EKA } \\
\text { RAHMADANI }\end{array}$ & 71 \\
\hline 8. & 1743 & $\begin{array}{l}\text { ERZA ADHITYA } \\
\text { MAULANA }\end{array}$ & 65 \\
\hline 9. & 1744 & FARHAN AZIZI & 75 \\
\hline 10. & 1745 & $\begin{array}{l}\text { FATHIR SYAH } \\
\text { AMIR SITOMPUL }\end{array}$ & 70 \\
\hline 11. & 1746 & $\begin{array}{l}\text { HAFRIZA } \\
\text { HASANAH }\end{array}$ & 71 \\
\hline 12. & 1747 & HALIZA AZURA & 72 \\
\hline 13. & 1748 & $\begin{array}{l}\text { ICAH ARDANI } \\
\text { PURBA }\end{array}$ & 68 \\
\hline 14. & 1750 & IMAM ADITYA & 81 \\
\hline 15. & 1751 & $\begin{array}{l}\text { JAKA BAGUS } \\
\text { PANGESTU }\end{array}$ & 78 \\
\hline 16. & 1752 & $\begin{array}{l}\text { JOYCE FEBRYAN } \\
\text { BANGUN }\end{array}$ & 80 \\
\hline 17. & 1753 & KEVIN BACTIAR & 82 \\
\hline 18. & 1754 & $\begin{array}{l}\text { MEIKA ANANDA } \\
\text { PRISKARINI }\end{array}$ & 81 \\
\hline 19. & 1755 & $\begin{array}{l}\text { MHD. ARIF } \\
\text { IRAWAN }\end{array}$ & 70 \\
\hline 20. & 1756 & $\begin{array}{l}\text { MHD. AZLI } \\
\text { PRADANA }\end{array}$ & 71 \\
\hline 21. & 1757 & $\begin{array}{l}\text { MHD. HALIM } \\
\text { NUROHO }\end{array}$ & 68 \\
\hline 22. & 1758 & $\begin{array}{l}\text { MHD. REZA } \\
\text { ALFIANDA }\end{array}$ & 82 \\
\hline 23. & 1759 & M. FAUZAN & 75 \\
\hline 24. & 1813 & $\begin{array}{l}\text { M. RAMZI } \\
\text { REKSADANA }\end{array}$ & 73 \\
\hline 25. & 1760 & $\begin{array}{l}\text { M. SYURAIH AL } \\
\text { HAQUE }\end{array}$ & 73 \\
\hline 26. & 1761 & $\begin{array}{l}\text { NABILA } \\
\text { KHAIRUNNISA }\end{array}$ & 70 \\
\hline 27. & 1762 & NADILA SIFHA & 66 \\
\hline 28. & 1763 & $\begin{array}{l}\text { NAJWA AULIA } \\
\text { SARAGIH }\end{array}$ & 72 \\
\hline 29. & 1764 & $\begin{array}{l}\text { NAZWA } \\
\text { AZRININDITA }\end{array}$ & 75 \\
\hline 30. & 1769 & $\begin{array}{l}\text { REISNA } \\
\text { SYAFITRI } \\
\end{array}$ & 75 \\
\hline 31. & 1767 & RIDHO ARYA & 75 \\
\hline 32. & 1768 & RIZKI RIANDA & 66 \\
\hline 33. & 1770 & $\begin{array}{l}\text { SAMUEL } \\
\text { RAPINDO } \\
\text { MANURUNG } \\
\end{array}$ & 72 \\
\hline 34. & 1729 & $\begin{array}{l}\text { SISKA EFA } \\
\text { ANGGRAINI }\end{array}$ & 75 \\
\hline 35. & 1896 & $\begin{array}{l}\text { SIVANA } \\
\text { MAWADDAH }\end{array}$ & 70 \\
\hline
\end{tabular}




\begin{tabular}{|c|c|l|c|}
\hline 36. & 1771 & $\begin{array}{l}\text { SUCI } \\
\text { NURHIDAYAH }\end{array}$ & 75 \\
\hline 37. & 1773 & SYARIFUDDIN & 74 \\
\hline 38. & 1775 & $\begin{array}{l}\text { ZAHWA AULIA } \\
\text { SAFYAN }\end{array}$ & 78 \\
\hline Jumlah & $\mathbf{2 7 9 4}$ \\
\hline \multicolumn{2}{|l|}{ Rata-rata } & $\mathbf{7 3 , 5 2}$ \\
\hline \multicolumn{2}{|l|}{ Ketuntasan } & $\mathbf{8 6 , 6 8 \%}$ \\
\hline
\end{tabular}

dilaksanakan walaupun tindakan tertentu masih belum optimal.

b. Dapat membimbing dengan penuh kesabaran dan perhatian.

c. Pujian kepada siswa dapat memotivasi untuk selalu aktif

Kendala

a. Guru tergesa-gesa dalam menyampaikan materi dan instruksi kepada siswa karena terikat waktu

b. Guru kurang memberikan kesempatan bertanya pada siswa.

Faktor Guru

a. Semua tindakan yang direncanakan sudah dapat

Penganalisaan Data

Tabel Reduksi Data Hasil belajar Pkn siswa SD Negeri 164518 kelas V

\begin{tabular}{|c|c|l|c|c|c|}
\hline No. & NIS & Nama Siswa & Pra Siklus & Siklus I & Siklus II \\
\hline 1. & 1737 & ALYA SUWITA & 70 & 72 & 75 \\
\hline 2. & 1738 & ANGELICA THANIA & 71 & 73 & 75 \\
\hline 3. & 1739 & ANGGI RAMADHANI & 65 & 70 & 75 \\
\hline 4. & 1740 & ARIF FATULLAH & 63 & 67 & 72 \\
\hline 5. & 1741 & DISTI AMELIA PUTRI & 66 & 70 & 70 \\
\hline 6. & 1742 & DIVA HABIBAH Br. SIMBOLON & 72 & 75 & 78 \\
\hline 7. & 1893 & EKA RAHMADANI & 68 & 68 & 71 \\
\hline 8. & 1743 & ERZA ADHITYA MAULANA & 55 & 63 & 65 \\
\hline 9. & 1744 & FARHAN AZIZI & 72 & 75 & 75 \\
\hline 10. & 1745 & FATHIR SYAH AMIR SITOMPUL & 64 & 68 & 70 \\
\hline 11. & 1746 & HAFRIZA HASANAH & 71 & 71 & 71 \\
\hline 12. & 1747 & HALIZA AZURA & 63 & 68 & 72 \\
\hline
\end{tabular}




\begin{tabular}{|c|c|c|c|c|c|}
\hline 13. & 1748 & ICAH ARDANI PURBA & 65 & 67 & 68 \\
\hline 14. & 1750 & IMAM ADITYA & 80 & 81 & 81 \\
\hline 15. & 1751 & JAKA BAGUS PANGESTU & 75 & 77 & 78 \\
\hline 16. & 1752 & JOYCE FEBRYAN BANGUN & 78 & 80 & 80 \\
\hline 17. & 1753 & KEVIN BACTIAR & 81 & 82 & 82 \\
\hline 18. & 1754 & MEIKA ANANDA PRISKARINI & 77 & 80 & 81 \\
\hline 19. & 1755 & MHD. ARIF IRAWAN & 65 & 70 & 70 \\
\hline 20. & 1756 & MHD. AZLI PRADANA & 67 & 68 & 71 \\
\hline 21. & 1757 & MHD. HALIM NUROHO & 63 & 67 & 68 \\
\hline 22. & 1758 & MHD. REZA ALFIANDA & 80 & 80 & 82 \\
\hline 23. & 1759 & M. FAUZAN & 72 & 73 & 75 \\
\hline 24. & 1813 & M. RAMZI REKSADANA & 70 & 71 & 73 \\
\hline 25. & 1760 & M. SYURAIH AL HAQUE & 69 & 70 & 73 \\
\hline 26. & 1761 & NABILA KHAIRUNNISA & 63 & 67 & 70 \\
\hline 27. & 1762 & NADILA SIFHA & 58 & 62 & 66 \\
\hline 28. & 1763 & NAJWA AULIA SARAGIH & 70 & 71 & 72 \\
\hline 29. & 1764 & NAZWA AZRININDITA & 70 & 71 & 75 \\
\hline 30. & 1769 & REISNA SYAFITRI & 70 & 72 & 75 \\
\hline 31. & 1767 & RIDHO ARYA & 75 & 75 & 75 \\
\hline 32. & 1768 & RIZKI RIANDA & 64 & 65 & 66 \\
\hline 33. & 1770 & SAMUEL RAPINDO MANURUNG & 71 & 71 & 72 \\
\hline 34. & 1729 & SISKA EFA ANGGRAINI & 70 & 72 & 75 \\
\hline 35. & 1896 & SIVANA MAWADDAH & 66 & 67 & 70 \\
\hline 36. & 1771 & SUCI NURHIDAYAH & 75 & 75 & 75 \\
\hline 37. & 1773 & SYARIFUDDIN & 65 & 70 & 74 \\
\hline 38. & 1775 & ZAHWA AULIA SAFYAN & 73 & 75 & 78 \\
\hline \multicolumn{3}{|r|}{ Jumlah } & 2632 & 2719 & 2794 \\
\hline
\end{tabular}




\begin{tabular}{|l|c|c|c|}
\hline Rata-rata & 69,26 & 71,55 & 73,52 \\
\hline Ketuntasan & $55,26 \%$ & $68,42 \%$ & $\mathbf{8 6 , 6 8 \%}$ \\
\hline
\end{tabular}

\section{Pembahasan Penelitian}

Berdasarkan tabel di atas, kita dapat melihat bahwa hasil belajar Pkn siswa kelas V SD Negeri 164518 kota Tebing Tinggi setelah menggunakan metode pembelajaran jigsaw menunjukkan adanya peningkatan baik dari pra siklus maupun hasil belajar siswa pada setiap siklus, dimana rata-rata hasil belajar siswa pada siklus I adalah sebesar 71,55 dan rata-rata hasil belajar siswa pada siklus II sebesar 73,52. Berdasarkan nilai KKM 70.

Berdasarkan tabel reduksi hasil belajar di atas, menunjukkan adanya peningkatan ketuntasan belajar siswa (\%) yang sudah tuntas secara klasikal pada setiap siklus, dimana pada siklus I terdapat $68,42 \%$ siswa yang sudah tuntas sedangkan pada siklus II terdapat $86,68 \%$ siswa yang sudah tuntas.

Dari tabel tersebut, rata-rata nilai siswa pada siklus I sampai siklus II cenderung mengalami peningkatan. Peningkatan nilai siswa tersebut setelah siswa mengikuti pelajaran Pkn dengan menggunakan metode pembelajaran jigsaw.

\section{Siklus 1}

Pelaksanaan siklus I dilaksanakan pada 20 September 2014. Kegiatan guru dalam metode pembelajaran jigsaw kurang diperhatikan guru untuk dilaksanakan seperti berdiskusi dengan siswa dalam menyelesaikan masalah dalam soal dan menjawab. Secara umum, ketuntasan pelaksanaan pembelajaran yang dilakukan guru pada siklus I baru mencapai $68,42 \%$.

Berdasarkan hasil analisis deskriptif terhadap hasil belajar siswa pada siklus I dengan skor minimum sebesar 62, nilai maksimum sebesar 82, rata-rata hasil belajar siswa sebesar 71,55. Pada kondisi ini ternyata terdapat 12 orang siswa yang belum tuntas karena memperoleh nilai di bawah KKM yang telah ditentukan oleh sekolah yaitu $\geq 70$, dan 26 orang siswa atau $68,42 \%$ siswa yang sudah tuntas karena memperoleh nilai $\geq 70$.

Dalam pembelajaran ini tampak bahwa siswa masih cenderung pasif dalam menerima pelajaran dari guru, artinya bahwa siswa masih cenderung mendengarkan penjelasan guru, kurang membaca buku teks atau LKS, dan kurang berdiskusi baik sesama siswa maupun kepada guru. Selain itu pula, kurangnya pemahaman siswa dalam menyelesaikan soal-soal Pkn sehingga berdampak pada kemampuan siswa menyelesaikan soal-soal sehubungan dengan materi. Berdasarkan beberapa aspek tersebut di atas diduga berpengaruh pada hasil belajar Pkn siswa, khususnya bagi siswa yang belum mencapai KKM. 
Setelah melakukan analisis dan refleksi pada siklus I, para observer dan peneliti mencoba mengadakan beberapa perbaikan dalam proses belajar mengajar diantaranya penekanan dalam pengorganisasian siswa belajar yang ditempuh dengan mengadakan diskusi baik dengan guru maupun dengan sesama siswa.

\section{Siklus II}

Pelaksanaan siklus II ini dilaksanakan pada 08 Oktober 2014. Berdasarkan hasil analisis deskriptif terhadap aktivitas siswa pada siklus II menunjukkan adanya peningkatan aktivitas siswa yang sangat signifikan dari siklus I. Selain itu juga, pada siklus II ini, ada beberapa aktivitas siswa yang berhasil ditingkatkan dari kategori kurang menjadi kategori baik diantaranya berdiskusi dengan teman dalam menyelesaikan soal-soal dan menjawab.

Peningkatan rata-rata aktivitas siswa menandakan bahwa siswa mulai aktif dalam mengikuti metode pembelajaran jigsaw. Peningkatan rata-rata siswa pada setiap siklus tersebut menandakan bahwa siswa mulai aktif dalam mengikuti pembelajaran. Hasil observasi yang dilakukan peneliti menunjukkan bahwa pelaksanaan pembelajaran dengan penerapan metode pembelajaran jigsaw dapat memberikan hasil yang lebih baik walaupun masih terdapat satuan aktivitas yang tidak mengalami peningkatan yang signifikan.
Berdasarkan hasil yang diperoleh pada tindakan siklus II, ketuntasan materi dan hasil observasi, maka penelitian ini dihentikan pada tindakan siklus II. Indikator keberhasilan dalam segi proses sudah tercapai yaitu minimal $85 \%$ proses pelaksanaan tindakan telah sesuai dengan skenario pembelajaran.

Berdasarkan hasil analisis deskriptif terhadap hasil belajar siswa pada setiap siklus menunjukkan bahwa penerapan metode pembelajaran jigsaw mampu meningkatkan hasil belajar siswa sehingga tampak bahwa pembelajaran yang dilakukan dalam penelitian ini lebih terpusat pada siswa (student centre), dimana peran guru dalam pembelajaran hanya bersifat sebagai mediator.

Berdasarkan hasil penelitian terhadap siswa kelas V Negeri 163089 kota Tebing Tinggi terjadi peningkatan hasil belajar dari siklus I ke siklus II. Hal ini disebabkan karena: Interaksi Guru

a) Guru mengorganisasikan waktu pembelajaran dengan baik.

b) Guru memberi motivasi dan apersepsi kepada siswa.

c) Guru mengikuti langkah-langkah pembelajaran yang terdapat dalam rencana pelaksanaan pembelajaran.

d) Guru mengarahkan dan memotivasi siswa untuk bertanya dan menyampaikan masukan.

e) Guru memberikan kesempatan kepada siswa untuk menjelaskan 
kembali pengetahuan yang telah diperolehnya.

f) Guru memberikan penghargaan berupa pujian kepada siswa ketika maju ke depan kelas dan inilah yang membuat siswa lebih baik.

Interaksi Siswa

a) Siswa mampu beradaptasi dengan strategi pembelajaran yang diterapkan.

b) Siswa memperhatikan penyampaian guru dan bersungguh-sungguh dalam belajar. Hal ini terlihat ketika guru melakukan tanya jawab terjadi umpan balik dari siswa meski ada saja siswa yang belum aktif.

c) Siswa aktif dalam memberi respon dalam kegiatan apresiasi.

d) Siswa cukup baik dalam menyimpulkan bahan ajar atau titik tekan materi yang telah diajarkan.

e) Siswa cukup baik dalam mengulangi atau menjelaskan kembali pengetahuan yang telah diperolehnya.

Interaksi Siswa dan Guru

a) Guru terampil dalam memandu diskusi siswa. Sehingga aktivitas ini dapat membantu meningkatkan hasil belajar siswa tentang materi yang diajarkan.

b) Siswa antusias untuk mengemukakan kesulitannya dalam menyusun dan menyelesaikan soal dan meminta bantuan atau bimbingan guru.

\section{KESIMPULAN}

Setelah melalui pelaksanaan penelitian tindakan kelas, maka penelitian yang berjudul: "Meningkatkan Hasil Belajar Siswa Mata Pelajaran PKN Menggunakan Metode Pembelajaran tipe Jigsaw Kelas V SD Negeri 164518 Kota Tebing Tinggi Tahun Pelajaran 2014/2015" dapat diperoleh hasil sebagai berikut:

Bahwa prestasi belajar PKn siswa Kelas V SD Negeri 164518 yang aktif mengikuti kegiatan belajar dengan menggunakan tipe belajar Jigsaw kelas V SD Negeri 164518 mengalami peningkatan dari siklus ke siklus, pada prasiklus diperoleh: 55,26, siklus I: 68,42 , dan menjadi 86,68 pada siklus ke II. Sehingga, dengan diadakannya pembelajaran dengan menggunakan tipe belajar Jigsaw dapat meningkatkan hasil belajar Pkn pada siswa Kelas V SD Negeri 164518 Kota Tebing Tinggi Tahun Pelajaran 2014/2015.

Agar tujuan pendidikan dapat tercapai secara optimal khususnya pada mata pelajaran PKn maka dalam pelajarannya penulis menggunakan tipe belajar Jigsaw pada siswa Kelas V SD Negeri 164518 Kota Tebing Tinggi Tahun Pelajaran 2014/2015.

1. Guru hendaknya menciptakan situasi kelas menjadi hidup yang dapat memberikan motivasi kepada anak didik yang mengarah kepada cara belajar aktif.

2. Dalam mengajar Pkn usaha selalu menggunakan situasi yang 
ada pada masyarakat, hal ini menambah lebih mendalam dalam mendalami pendidikan Pancasila dan Kewarganegaraan.

3. Dengan pemberian tugas diharapkan mampu meningkatkan aktifitas belajar siswa sehingga disarankan bahwa dengan menggunakan tipe belajar Jigsaw maka siswa makin sering belajar, maka diharapkan hasil belajarnya akan meningkat.

4. Sebagai pendidik yang dinamis, keharusan baginya selalu mengikuti kemajuan dan perkembangan jaman terutama di bidang pembaharuan dalam pendidikan. Oleh sebab itu guru dituntut mengembangkan alatalat dan metode-metode pendidikan yang lebih relevan dan konsisten pada tujuan pendidikan.

\section{DAFTAR RUJUKAN}

Ahmad, Abu, H. 1989. Pengantar Metode Didaktik. Bandung: CV. Armico.

Bachtiar, Harsya W. 1984. Media Pendidikan. Bandung: Rajawali.
GBHN. 1993. Garis-Garis Besar Haluan Negara. Surabaya: Arkola.

Hadi. Sutrisno. 1987. Statistik II. Yogyakarta: Yayasan Penerbit Fakultas Psikologi UGM.

Hamalik, Oemar. 1994. Media Pendidikan. Bandung: Citra Aditya Bakti.

H.R.L. Zainuddin. 1978. Media Dalam Pembelajaran. Jakarta: Pusat Sumber Belajar.

Nawawi, Hadiri H. 1993. Metode Penelitian Bidang Sosial. Yogyakarta: Gadjahmada Universitas Press.

Surakhmad, Winarno. 1985. Pengantar Penelitian Ilmiah. Bandung: Tersito.

Sardiman, A. 1992. Interaksi dan Motivasi Belajar Mengajar. Bandung: Rajawali Press.

Walgito, Bimo. 1982. Bimbingan dan Penyuluhan di Sekolah. Yogyakarta: Yayasan Penerbit Fakultas Psikologi UGM. 